\title{
Does Conditionality on Borrowing Help?
}

\author{
Prince Eyi-Mensah \\ Correspondence: Prince Eyi-Mensah, School of Economics, Huazhong University of Science and Technology, China \\ E-mail: phamsika@yahoo.co.uk.
}

Received: March 16, 2016

doi:10.5539/ibr.v9n7p12

\author{
Accepted: April 5, 2016 \\ Online Published: April 20, 2016 \\ URL: http://dx.doi.org/10.5539/ibr.v9n7p12
}

\begin{abstract}
Borrowers of international financial institutions (IFIs) have both interest and conditionality to deal with. Using data from the World Governance Indicators (WGI), we investigated the influence of conditionality on borrowers. By applying a dynamic panel regression method, we found compelling evidence, which supports our intuition that conditionality increases the debt burden of borrowing countries. However, this was not the case for all the indebted countries. Heavily indebted poor countries (HIPC) had some of their external commitments reduced when they agreed to implement some sets of conditionality. In light of these findings, we posit that the advocated structural reforms which is used, as a justification for prescribing conditionality does not materialize as planned. It however, erodes the capacity of borrower countries toward their debt servicing obligations. A direct consequence is their incessant need for external development assistance. Results of the study also proved robust.
\end{abstract}

Keywords: external commitment, conditionality, IFI and institutions

\section{Introduction and Motivation}

Evidence has shown that it is relatively less difficult to acquire external assistance than paying back. The request and payment stages are fraught with actions that affect the borrowing countries and territories, chief among them being conditionality prescriptions. The latter has been justified in different reports, however we formally adduce reasons through empirical modeling to show this phenomenon to be one of the cardinal reasons for the debt overhang of borrowing countries.

An additional reason behind the carrying out of our investigation stems from the survey of institutional literature we did. Conditionality comes in different forms but typically; they are geared towards structural and governance reform. That qualifies it as one of the institutional policy changes mentioned in institutional literatures. An interesting fact about it is that though strong in its impact on borrowing countries and their institutions, it comes from outside. Some of its effects have been documented in existing studies.

National governments in their bid to keep at doing state business of providing public goods and services (for the realization of national development goals) do need funds to make that possible. The primary sources of the said funds are taxes, and other forms of revenue like the one from state owned enterprises among others. According to Besley and Persson (2010), least developed countries have state extraction machines with low fiscal capacity. This is evident in their lack of knowledge about the economic actors in their respective economies, what they do and how much to collect from them? These add up to deficiencies that result in low tax revenue, which they have been enduring. Revenue from state owned enterprises is another tricky issue. Since keeping citizens employed is of primary importance to these enterprises, strategies that engender profits are often relegated to the background. Therefore, it is always difficult to rely on these two sources to finance their budgets.

Commodity price fluctuations have had the most telling effect on these groups of countries. Some cite this as the reason for which they need support. Others mention it as the reason why their lenders (development partners) should consider extending some form of moratorium to them towards their debt servicing obligations. Before we proceed, any further one thing needs to be clarified, which is all nations borrow. Ordinarily, tax, government securities, quality Euro bonds among others should be good enough to provide credit for government business to run uninterruptedly. This is not just the first source of credit but also a signal of how healthy an economy is and otherwise for external assistance.

In order not to make out loans that are doomed from the outset, creditors first started issuing directives that list some extra obligations to make repayments a certainty. With time, these obligations were christened into conditionality warranting economic reforms in assisted countries. At some point, a careful obedience to these requirements carried weight akin to repayment efforts. This could be seen in the reward of receiving extra development assistance or the 
curtailing of further assistance to non-obliging countries and territories respectively.

Assistance seeking countries do not have the prerogative to choose their own line of reform, but instead have to heed the directives of IFI assessment experts. The conditionality that make up the set of reform objectives are in most cases very specific from the number of employees of state parastatals (SP) among others to be laid-off to which SP to be privatized among others. Ownership of such reform policies though well intended (as they have been constantly reiterated) has been very difficult. The consequences of the aforementioned reforms are and can be far reaching.

Countries have inherited debts (Krugman, 1988) and have structural issues that go with it. These countries periodically seek assistance not only to finance new programs and projects, but also to take care of their old debt servicing obligations. Fafchamps (1996) made mention of a trap: "where the debt overhang persist, debt rescheduling takes place periodically, and conditionality continues indefinitely." This is what our study sets out to investigate empirically.

The rest of the paper is as follows: section 2 briefly reviews existing literature. Section 3 presents our empirical strategy and data. Section 4 reports the results of the effects of conditionality on borrowing countries. Section 5 reports our robustness test results, while section 6 concludes.

\section{Summary Literature}

Lending and its associated issues received a lot of attention in the 80's and 90's. Most of the discussions that were formalized were reported theoretically. Studies in that period focused on modeling the nature of sovereign debt, threat of default and the justification of prescribing conditionality to mitigate the incentive problem. Our focus is on how the threat of repudiation has changed assistance contract. Specifically how lenders for fear of loosing their investments have taking steps to ensure loan servicing and its effect on borrowers. The first part of this review reports the foundation of our claim. The second part discusses issues that drum home the need for our study. For the former Eaton and Gersovitz (1981) claimed that the difference between lending to developed nations and least developed countries (LDC's) was the threat of possible repudiation.

Other scholars have investigated sovereign risk too. Among them were Sachs and Cohen (1982), who modeled default risk on international lending to LDC's. Their study reported how the threat has shaped the international lending landscape. Kletzer (1984) discussed the debt crisis emanating from the risk mentioned above. His model emphasized the role of asymmetric information about the total debt-servicing obligations between creditors and debtors. Subsequent studies tried to address the weaknesses in earlier works.

Sachs (1989) models the different situation that causes a gap to exist between theory and what pertains in practice. His solution was to model government with limited taxing authority. Still on the subject of filling in the gap, Worrall (1990) modeled a situation where countries are allowed to repudiate. The latter was on condition that by repudiating the country gained an advantage. His model explained how consumption is stabilized in the long run, even when debt is initially restricted.

Krugman's (1988) study examined the tradeoff facing creditors of countries with unsustainable debt burdens. The paper suggested how the tradeoff could be improved. Stiglitz (2000) on the other hand argued that, "In many cases, however, outsider lenders are as fully informed as domestic politician." That claim is an apt representation of our view on the amount of information available to creditors and debtors. This makes it possible for borrowers to fall into the debt trap present in the international loan market. Fafchamps (1996) mentioned pre-emption of conditionality as a precursor of the trap. Stiglitz's report shows that the IFIs are not unaware of the facts. We therefore believe that some countries and territories may have already fallen into the trap warranting our inquiry.

Other proponents of conditionality like Payer (1975) described as too much the Fund's focus on internal adjustment. Pointing out that the Fund's, preoccupation with the latter process relegates development to the background. Feldstein (1998), Radelet and Sach (1998) have all reported on the nature of conditionality prescribed by the IMF. They reported that the Fund's structural reform directives are detracting. They argued that it affects the borrowing countries credit worthiness, by sending the wrong signal to potential private lenders who will like to do business with them. Loxley (1986) poses questions on who should pay for the balance of payment of adjustment. Dell $(1981,1982)$ reports that conditional loans are unimportant and argues that the origins of crisis are important factors to consider instead.

According to Goldstein (2003); Dreher (2004); Dreher \& Jensen (2003) and Dreher Sturm and Vreeland (2009), politically weak countries are saddled with stronger conditionality. Kapur and Webb (2000) have also reported that when conditionality is broadly defined Sub Saharan African countries carry the most burdens, however Abdildina and Jaramillo-Vallejo (2005) think it has reduced. Koeberle (2004); Khan and Sharma (2001); IMF (2001); Drazen and Isard (2004) have all put some effort into defining and discussing ownership of conditionality.

Among the reasons used for the justification of conditionality are debt servicing and repayment. Literature that discusses these issues can be categorized into five groups. One group has commitment at its core [Dhonte (1997); Rodrik (1992); 
Fafchamps (1996); Sachs (1989); Drazen (2006)]; the other has persuasion [Spraos (1986); Cornelius (1988); Khan and Sharma (2001)]. The other three investigate signaling [Bird (1977); Marchesi and Thomas (1999)], restrictions [Buchanan (1968); Garfinkel (1973); Little and Clifford (1965)] and remedy [Vaubel (1983, 1991); Bruce and Waldman (1991); Dreher and Vaubel (2004), Svensson (2000)]. For a critique of the above studies, see Dreher (2009).

Raffer (1993) reports the sheer neglect of northern countries concerning accountability of IFIs. His proposed solution to make them more accountable includes: debt reduction, discontinuation of bad economic programs among others. Kapur and Webb (2000) justified the use of conditionality at the instance of transfers. They reason with Fafchamps (1996) on the issue. Killick (1995) has argued that over reliance on conditionality has bred a habit of non-compliance.

The literature summarized above share a commonality, which is the analytical framework used is either theoretical or qualitative. That clearly shows the need for a study such as ours. This study fills the gap between the qualitative and theoretical with an empirical analysis of available data. This allows us to report the extent (in quantitative terms) to which conditionality affect borrowing countries.

\section{Empirical Strategy and Data}

\subsection{Governance Related Conditionality (GRC)}

GRCs are policy directives that aim at engendering legislative and institutional building efforts in borrowing countries. It is to foster the rule of law and increase transparency, accountability and participation. Kapur and Webb (2000) argue the difficulty in defining terms like governance and what constitute conditionality. One thing we have to bear in mind is that, their study was qualitative. So reporting on quantitative difficulties may be a little troubling for authors who have their eyes set on doing any form of econometric modeling on the subject. The issues to resolve included scores to assign to categorical terms like "adopt", "assess", "authorize", "build upon" among others.

To overcome this problem the study opted for the World Governance Indicator (WGI) data. This is a perception-based measure for institutional efficiency in over 200 countries and territories. The six indicators of the WGI are as follows. Voice and accountability (VA), which captures perceptions of the extent to which a country's citizens are able to participate in selecting their government, as well as freedom of expression, freedom of association, and a free media. Political stability and absence of violence/terrorism (PV), which captures perceptions of the likelihood that the government will be destabilized or overthrown by unconstitutional or violent means, including politically - motivated violence and terrorism. Government effectiveness (GE); captures perceptions of the quality of public services, the quality of the civil service and the degree of its independence from political pressures, the quality of policy formulation and implementation, and the credibility of the government's commitment to such policies. Regulatory quality (RQ): captures perceptions of the ability of the government to formulate and implement sound policies and regulations that permit and promote private sector development. Rule of law (RL): captures perceptions of the extent to which agents have confidence in and abide by the rules of society, and in particular, the quality of contract enforcement, property rights, the police, and the courts, as well as the likelihood of crime and violence. Control of corruption (CC): captures perceptions of the extent to which public power is exercised for private gain, including both petty and grand forms of corruption, as well as "capture" of the state by elites and private interests.

The challenge was on how to convert these into measures to capture the often-agreed on prescriptions of the IFIs. The index scores an institution a minus, when the perception gathered on it indicates that it is not functioning effectively (with a score of -2.5 being the worst) and a positive if otherwise (with 2.5 being the best score). Our way out was to create dummy variables that were representative of the set of conditionality needed for our analysis. We needed a threshold to help us delineate the latter. An institution with a positive score will not be required to accept any prescription when it borrows. With reference to the latter it means a negative score makes the country subject to a set of GRC. The values of the six indicators are highly correlated so picking any of them would be representative of the whole. Our picks to proxy for conditionality were based on factors mentioned in institutional studies as being important for economic growth. Introducing these dummy variables into our regression equation presupposes that the borrower has agreed upon the prescription which the dummy variable proxy for.

We chose voice of accountability, which after the treatment proxy for the directive to improve participation and ensure individual rights and freedoms (it is represented by VAC). Government efficiency conditionality (GEC) proxy for the directive to improve the capacity of government to effectively formulate and implement sound policies. Regulatory quality conditionality (RQC) proxy for the directive for the strengthening of state machinery to implement policy and regulations that permits and promotes private sector development. The last treatment was given to the corruption control indicator to proxy for the conditionality for the fight against graft (becoming corruption control conditionality-CCC).

We assembled a panel data set from the World Bank data hub for our analysis. We took care of the trend issue with the debt series and relied on our empirical specification and dynamic panel estimator to cater for the autocorrelation 
problem. An additional estimation treatment was to include one lag of the dependent variable as a covariate. With a specification like that, the linear dynamic panel data model will contain unobserved panel-level effects, fixed or random. Arellano and Bond (1991) dynamic panel data-model derives a consistent generalized method of moments (GMM) estimator for the parameters of this model; xtabond implements this estimator. The unobserved panel-level effects are correlated with the lagged dependent variables, making standard estimators inconsistent. Solution to that will be given later.

\subsection{Basic Specification}

$$
y_{i t}=y_{i t-1} \gamma+x_{i t}^{\prime} \beta_{1}+w_{i t} \beta_{2}+u_{i}+\epsilon_{i t} i=1, \ldots, N ; t=1, \ldots, T
$$

Where $y$ is the dependent variable (log external commitments) for country $i$ at time $t$. The first term is the dependent variable lagged one time. The second term is the control matrix (which include a time variable to remove any trend that may exist in the observed changes in the dependent variable and subsequent additions after the association between external commitments and conditionality is established). The third term denotes the conditionality regressor. This makes $\beta_{2}$ the coefficient of interest. $u_{i}$ captures the unobserved individual level effect, and it's correlated with the first term. The last term is the error term. All exogenous variables in our specification each contribute one instrumental variable (IV) to our IV matrix. The remaining IVs come from the $p-2$ (where $p$ is the periods) instruments available in the periods being run. The GMM estimator and the IV's solve the autocorrelation problems mention earlier. We chose to report robust standard errors instead of the default General Method of Moments (GMM) errors. Specifying the variance of clustered estimator (VCE) (robust) produced and estimated VCE that is robust to heteroskedasticity. Reporting the latter instead of the GMM meant that our overidentifying conditions could not be done using the Sargan test, so we checked for autocorrelation instead. Our null hypothesis for this test was rejected, indicating that our specification was free from autocorrelation.

\subsection{Descriptive Statistics}

The study's focus is on countries that have external commitments, to their official creditors (the values are reported in current US\$). External commitments are the amount of long-term loans for which contracts were signed in the year specified. Debt from official creditors includes loans from international organizations (multilateral loans) and loans from governments (bilateral loans). Loans from international organization include loans and credits from the World Bank, regional development banks, and other multilateral and intergovernmental agencies. Excluded are loans from funds administered by an international organization on behalf of a single donor government; these are classified as loans from governments. Government loans include loans from governments and their agencies (including central banks), loans from autonomous bodies, and direct loans from official export credit agencies. Data are in current U.S. dollars. Table1 summarizes our data. The second and third columns report observations, means with their standard deviations below them.

\section{Empirical Results}

\subsection{Relationship between Debt and Conditionality}

This section reports the relationship between debt and conditionality. Voice of accountability conditionality had a positive relationship with debt for the whole sample and the group of countries that were not qualified for the heavily indebted poor countries (HIPC) program-we referred to them as the Non-HIPC subsample. Meaning the prescribed single set of conditionality increased the external debt owed to the official creditors of the borrowing countries.

In general, our benchmark results, which are reported in Table 2 section A, are mostly consistent with the other estimated results in Table 2, section B and C. Therefore, instead of interpreting every single one of the results we chose to summarize our claims from the observed commonalities. Holding multi party election is one of the policies that have to be implemented by a country that has VAC as a prescribed conditionality. Electioneering cost and the running of deficits to win public approval all run up the bill for borrower countries. Democracy is always a good sell, when it comes to making assistance request. When those requests are honored, the external commitments of borrower countries rise as a result. That is partly how the countries in our whole sample and the Non-HIPC group get their debts increased.

The implementation of the directive to improve government effectiveness increased the external debt of the countries in the Non-HIPC group by $26 \%$. It however reduced the external debt burden of the HIPC group by $34 \%$ (Table 2 section A). The values from which the dummy variable was created captures concept measures such as price control, discriminatory tariffs and excessive protection among others. Trying to fix them may entail formulating and implementing sound policies. Policies, that permits and promotes private sector development. Issues on trade liberalization in developing countries are well documented. Our interest is on how those practices affect debt. Multinational corporations (MNCs) are very good at avoiding taxes without breaking the law. This translates into fewer taxes for government. They drive nascent firms to the brink of extinction in their host countries with their production capacity and pricing system. 
Table 1. Descriptive Statistics

\begin{tabular}{|c|c|c|c|c|c|c|c|c|c|c|c|c|}
\hline \multirow[b]{2}{*}{ Series } & \multicolumn{4}{|l|}{ Whole Sample } & \multicolumn{4}{|l|}{ HIPC Group } & \multicolumn{4}{|c|}{ Non-HIPC Group } \\
\hline & Observation & Mean & Min & $\operatorname{Max}$ & Observation & Mean & Min & Max & Observation & Mean & Min & $\operatorname{Max}$ \\
\hline $\begin{array}{l}\text { Log external } \\
\text { commitments (to } \\
\text { official creditors) }\end{array}$ & 1834 & $\begin{array}{l}19.08743 \\
(1.836266)\end{array}$ & 9.10498 & 24.02628 & 552 & $\begin{array}{l}18.6104 \\
(1.503585)\end{array}$ & 12.38422 & 22.66064 & 1282 & $\begin{array}{l}19.29283 \\
(1.926694)\end{array}$ & 9.10498 & 24.02628 \\
\hline Interest rate & 2055 & $\begin{array}{l}2.222652 \\
(1.893178)\end{array}$ & 0 & 11.0169 & 652 & $\begin{array}{l}1.196918 \\
(1.040238)\end{array}$ & 0 & 7.9364 & 1403 & $\begin{array}{l}2.69933 \\
(2.007931)\end{array}$ & 0 & 11.0169 \\
\hline Grace period & 2038 & $\begin{array}{l}5.903767 \\
(6.03462)\end{array}$ & -223.7185 & 27.1667 & 652 & $\begin{array}{l}6.548732 \\
(9.735089)\end{array}$ & -223.7185 & 15.1517 & 1386 & $\begin{array}{l}5.600364 \\
(2.953958)\end{array}$ & 0 & 27.1667 \\
\hline $\begin{array}{l}\begin{array}{l}\text { Deficit as a } \\
\text { percentage } \\
\text { GDP }\end{array} \\
\text { of }\end{array}$ & 1030 & $\begin{array}{l}-1.982866 \\
(6.190346)\end{array}$ & -21.13655 & 129.504 & 270 & $\begin{array}{l}-1.412872 \\
(9.627153)\end{array}$ & -17.62496 & 129.504 & 760 & $\begin{array}{l}-2.185364 \\
(4.352896)\end{array}$ & -21.13655 & 26.2691 \\
\hline $\begin{array}{l}\text { Voice of } \\
\text { accountability } \\
\text { conditionality } \\
\text { (VAC) }\end{array}$ & 1734 & $\begin{array}{l}.7018454 \\
(.4575797)\end{array}$ & 0 & 1 & 545 & $\begin{array}{l}.8587156 \\
(.3486347)\end{array}$ & 0 & 1 & 1189 & $\begin{array}{l}.6299411 \\
(.4830233)\end{array}$ & 0 & 1 \\
\hline $\begin{array}{l}\text { Government } \\
\text { effectiveness } \\
\text { conditionality } \\
\text { (GEC) }\end{array}$ & 1717 & $\begin{array}{l}.8078043 \\
(.3941408)\end{array}$ & 0 & 1 & 545 & $\begin{array}{l}.987156 \\
(.1127048)\end{array}$ & 0 & 1 & 1172 & $\begin{array}{l}.7244027 \\
(.4470055)\end{array}$ & 0 & 1 \\
\hline $\begin{array}{l}\text { Regulatory } \\
\text { quality } \\
\text { conditionality } \\
\text { (RQC) }\end{array}$ & 1717 & $\begin{array}{l}.7751893 \\
(.4175792)\end{array}$ & 0 & 1 & 545 & $\begin{array}{l}.9743119 \\
(.1583484)\end{array}$ & 0 & 1 & 1172 & $\begin{array}{l}.6825939 \\
(.4656657)\end{array}$ & 0 & 1 \\
\hline $\begin{array}{l}\text { Corruption } \\
\text { control } \\
\text { conditionality } \\
\text { (CCC) }\end{array}$ & 1722 & $\begin{array}{l}.8455285 \\
(.3615052)\end{array}$ & 0 & 1 & 545 & $\begin{array}{l}.9577982 \\
(.2012341)\end{array}$ & 0 & 1 & 1177 & $\begin{array}{l}.7935429 \\
(.4049344)\end{array}$ & 0 & 1 \\
\hline
\end{tabular}

Standard deviations are in parenthesis below the mean values.

Table 2. One set of conditionality

\begin{tabular}{|c|c|c|c|c|c|c|c|c|c|c|}
\hline \multirow[b]{3}{*}{$\begin{array}{l}\text { Type } \\
\text { conditionality }\end{array}$} & \multirow[b]{3}{*}{ of } & \multicolumn{3}{|l|}{ A-Bench mark } & \multicolumn{3}{|c|}{ B - Cost without grace period } & \multicolumn{3}{|l|}{$\mathrm{C}-$ Full cost } \\
\hline & & \multicolumn{3}{|c|}{ 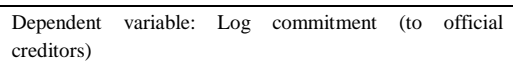 } & \multicolumn{3}{|c|}{$\begin{array}{l}\text { Dependent variable: Log commitment (to official } \\
\text { creditors) }\end{array}$} & \multicolumn{3}{|c|}{$\begin{array}{l}\text { Dependent variable: Log commitment (to official } \\
\text { creditors) }\end{array}$} \\
\hline & & Whole sample & HIPC group & $\begin{array}{l}\text { Non-HIPC } \\
\text { group }\end{array}$ & Whole sample & HIPC group & Non HIPC group & Whole sample & HIPC group & $\begin{array}{ll}\begin{array}{l}\text { Non } \\
\text { group }\end{array} & \text { HIPC }\end{array}$ \\
\hline $\begin{array}{l}\text { Voice } \\
\text { accountability } \\
\text { conditionality } \\
\text { (VAC) }\end{array}$ & of & $\begin{array}{l}.3888391 * * * \\
(.1426834)\end{array}$ & $\begin{array}{l}.4719899 \\
(.3283155)\end{array}$ & $\begin{array}{l}.2636916^{* *} \\
(.1273107)\end{array}$ & $\begin{array}{l}.3341674 * \\
(.1749498)\end{array}$ & $\begin{array}{l}.1840566 \\
(.4247466)\end{array}$ & $\begin{array}{l}.4392165^{* * * *} \\
(.1762034)\end{array}$ & $\begin{array}{l}.3382125^{* *} \\
(.1751409)\end{array}$ & $\begin{array}{l}.1746156 \\
(.4207786)\end{array}$ & $\begin{array}{l}.4110348^{* *} \\
(.1871665)\end{array}$ \\
\hline Prob $>$ chi2 2 & & 0.0000 & 0.0000 & 0.0000 & 0.0000 & 0.1644 & 0.0002 & 0.0000 & 0.1555 & 0.0001 \\
\hline $\begin{array}{l}\text { Government } \\
\text { efficiency } \\
\text { conditionality } \\
\text { (GEC) }\end{array}$ & & $\begin{array}{l}.1591769 \\
(.132507)\end{array}$ & $\begin{array}{l}-.3437358^{*} \\
(.207559)\end{array}$ & $\begin{array}{l}.261179^{*} \\
(.1458212)\end{array}$ & $\begin{array}{l}.1123201 \\
(.2031584)\end{array}$ & $\begin{array}{l}-.3280398 * \\
(.2003573)\end{array}$ & $\begin{array}{l}.034171 \\
(.200989)\end{array}$ & $\begin{array}{l}.1148099 \\
(.2029798)\end{array}$ & $\begin{array}{l}-.3243901^{*} \\
(.1780003)\end{array}$ & $\begin{array}{l}.0144837 \\
(.1974712)\end{array}$ \\
\hline Prob $>$ chi 2 & & 0.0000 & 0.0000 & 0.0000 & 0.0000 & 0.0108 & 0.0008 & 0.0000 & 0.0203 & 0.0005 \\
\hline $\begin{array}{l}\text { Regulatory } \\
\text { quality } \\
\text { conditionality } \\
\text { (RQC) }\end{array}$ & & $\begin{array}{l}.3365966^{*} \\
(.1878292)\end{array}$ & $\begin{array}{l}.8166134 * * * \\
(.2970656)\end{array}$ & $\begin{array}{l}.2499519 \\
(.2070559)\end{array}$ & $\begin{array}{l}.2379672 \\
(.1900534)\end{array}$ & $\begin{array}{l}.383365 \\
(.4641456)\end{array}$ & $\begin{array}{l}-.025224 \\
(.1796387)\end{array}$ & $\begin{array}{l}.237644 \\
(.189849)\end{array}$ & $\begin{array}{l}.3747367 \\
(.4440619)\end{array}$ & $\begin{array}{l}-.0283718 \\
(.1793562)\end{array}$ \\
\hline Prob $>$ chi 2 & & 0.0000 & 0.0000 & 0.0000 & 0.0000 & 0.1612 & 0.0018 & 0.0000 & 0.1559 & 0.0008 \\
\hline $\begin{array}{l}\text { Corruption } \\
\text { control } \\
\text { conditionality } \\
\text { (CCC) }\end{array}$ & & $\begin{array}{l}-.0894192 \\
(.2119309)\end{array}$ & $\begin{array}{l}-.5191355 * \\
(.3099995)\end{array}$ & $\begin{array}{l}.1027863 \\
(.2614488)\end{array}$ & $\begin{array}{l}.2247738 \\
(.2132169)\end{array}$ & $\begin{array}{l}-.0104156 \\
(.2196424)\end{array}$ & $\begin{array}{l}.1567066 \\
(.2604887)\end{array}$ & $\begin{array}{l}.222592 \\
(.2130221)\end{array}$ & $\begin{array}{l}-.0262448 \\
(.226041)\end{array}$ & $\begin{array}{l}.1693449 \\
(.2616723)\end{array}$ \\
\hline Prob $>$ chi 2 & & 0.0000 & 0.0000 & 0.0000 & 0.0000 & 0.0653 & 0.0016 & 0.0000 & 0.0257 & 0.0005 \\
\hline $\begin{array}{l}\text { Number } \\
\text { Observations }\end{array}$ & of & 979 & 293 & 686 & 584 & 164 & 420 & 584 & 164 & 420 \\
\hline
\end{tabular}

Robust standard errors are reported in parenthesis below the coefficients. $* * *$ indicate the coefficient is different from zero at the 1 percent level, **at the 5 percent level, and * at the 10 percent level.The resultant shrinkage means more unemployment in those countries. Government will have to come in with welfare policies to alleviate the plights of the unemployed. Furthermore, some MNCs have generous repatriation agreements with their host, which allow them to transfer their profits to preferred offshore destinations. This directly leads to less capital in the host economies, 
especially during periods when they need it most. Government business of providing public goods has to continue regardless. Therefore, if they cannot rely on local sources to fund their developmental programs they may look abroad. This is perhaps how the countries get their external commitments increased.

A set of regulatory quality prescription implemented over the period increased the external debt burden of the whole sample and the HIPC sample by $34 \%$ and $82 \%$ respectively (Table 2 section A). The implementation of conditionality on the fight against corruption yielded dividends for the HIPC group, as it reduced their indebtedness by $52 \%$ (Table 2 section $\mathrm{A})$.

In order to be able to make a solid claim for or against conditionality and its impact on debt, we increased the size of the control vector (the second term of the above equation). This we did by introducing the cost of borrowing (interest rate) and the reason for borrowing (deficit) into the control matrix for specification. The increase in the number of covariates reduces the area of influence of our conditionality proxy. This makes it possible to state clearly the impact of the latter on external debt or otherwise.

Agreeing to implement a voice of accountability prescription increased the external commitments of the whole sample by $33 \%$ and $44 \%$ (Table 2 section B) for the Non-HIPC group. However, a prescription of government effectiveness reduced the external commitments of the HIPC group by $33 \%$ (Table 2 section B). The views of respondents on primary education, public transportation, and basic health services among others cannot be changed if actual improvements are not seen. Changing these from bad to good will require a good financial outlay. This is perhaps a reason for the reported increase in the external commitments reported by the section of Table 2 captioned cost without grace period.

Grace period is an important item that needs to be considered when calculating the full value of assistance (Non-ODA facilities), and the true value of the burden borrowers carry. Theoretical studies on sovereign debt often focus on rescheduling, but we think the respite engendered by grace period needs to be accounted for. This was the last addition we made to the control matrix. Estimates from that specification are captured in the section of Table 2 captioned full cost. External debt for the whole sample and the Non-HIPC group increased, when VAC was given out as a directive for policy implementation just as the priors. The HIPC subsample experienced a reduction of $32 \%$ in their external debt when government effectiveness was improved.

\subsection{The Average Impact of Two Sets of Conditionality}

Adding government effectiveness to voice of accountability as a prescription increased the external commitments of the whole sample and the Non-HIPC group by 39\% and 34\% respectively (Table 3 section A). The situation was the same (with respect to the sign) for the implementation of the voice of accountability and regulatory quality, only this time the HIPC subsample also experienced an increase in their external debt commitments by $51 \%{ }^{1}$. When voice of accountability and corruption control was combined as a pair of conditionality, it had a positive correlation with debt for both the whole sample and Non-HIPC subsample.

Table 3, section A, shows that government effectiveness and corruption control prescription slashed off more than three quarters $(78 \%)$ of the external debt burden of the HIPC subsample. These countries are so far behind structurally that any positive shift in efficiency in their economies yields huge returns. The reported reduction in external commitments is a summation of that. For instance, one trained teacher in that part of the world may teach different subjects and many pupils in a day. Her workload may be several times bigger than that of her counterparts elsewhere in the developed world. It is the same with other infrastructures like schools and hospitals among others. In another instance one public amenity constructed may serve many communities. All the gains from the above coupled with that from their fight against corruption gives meaning to the reported estimate.

Overall countries that agreed to improve their voice of accountability and government effectiveness had a $37 \%$ increase in their external commitments. The magnitude was one percent more for the Non-HIPC subsample. By agreeing to implement the voice of accountability and regulatory quality, countries in the whole sample with those prescriptions experienced an increase in their external commitments. Voice of accountability and corruption control conditionality prescribed for countries in the whole sample and in the Non-HIPC subsample increased their external debt burden. The HIPC group experienced a reduction in their external commitment but this was not significant. Regulatory quality and corruption control implementation increased the external commitment of the countries that had such obligations.

Table 3, section C, reports increasing estimates for both the whole sample and the Non-HIPC subsample. None of the increases exceeded $40 \%$ in magnitude. Reported estimates for the HIPC subsample though decreasing were not significant.

\footnotetext{
1 Unless otherwise stated all interpreted results are significant at the $1 \%, 5 \%$ or $10 \%$ level.
} 


\subsection{Do the Impacts Differ When Three or More Sets of Conditionality Are Prescribed?}

Estimates to answer the above question are reported in Table 4 section A, B and C. From the latter's section A, an implementation of voice of accountability, government effectiveness and regulatory quality increased the external commitment of the whole sample, the HIPC and Non-HIPC subsamples. The magnitude was $41 \%$ for the whole sample, $45 \%$ for the HIPC subsample and 33\% for the Non-HIPC subsample. Countries that implemented voice of accountability, government effectiveness and corruption control, did not see improvement in their situation. Their external debt burden increased. The whole sample and the Non-HIPC subsample experienced the same kind of association as the one reported earlier. The four sets of conditionality implemented together also increased the debt situation for the whole sample by $36 \%$ and that of the Non-HIPC subsample by $30 \%$ (Table 4, section A).

The sets of voice of accountability, government effectiveness and regulatory quality prescriptions implemented increased the external commitment of the whole sample by $41 \%$ and $39 \%$ for the Non-HIPC subsample (Table 4, section B, column one cell one and three). The sign and magnitude of impact was nearly the same for the implementation of the voice of accountability, government effectiveness and corruption control conditionality. A three set conditionality made up of the voice of accountability, regulatory quality and corruption control implemented over the span of our study period increased the external commitment of the whole sample and the Non-HIPC subsample. It also increased when regressed on four sets of conditionality by a magnitude of $46 \%$ for the whole sample and $40 \%$ for the Non-HIPC subsample (find the said estimates in the bottom cells of Table 4 , section B, column one and three).

In general Table 4, section $\mathrm{C}$, reports estimates with signs just like the previous section, however the magnitudes are larger than that of the latter. For instance adding regulatory quality to voice of accountability and government effectiveness as an agreed set of policy directives increased the external commitment of the whole sample by $42 \%$. The estimate for the Non-HIPC subsample was almost the same. A policy directive to help step up the fight against corruption added to voice of accountability and government effectiveness also increased the external commitment of the whole sample $41 \%$ and $35 \%$ for the Non-HIPC subsample. The trend of significantly estimated results continued for the rest of the whole sample column and the Non-HIPC subsample except for one cell in the latter, which was not significant. Now, while these results mostly confirm the claims of Kapur and Webb, it does also fit the debt trap description made by Fafchamps. There is not much to show that prescribing conditionality to borrower countries will be ending anytime soon. Moreover borrowers are also not giving enough signal of wanting to wean themselves off seeking assistance from external sources, so the cycle continues.

Table 3. Two sets of conditionality

\begin{tabular}{|c|c|c|c|c|c|c|c|c|c|c|}
\hline \multirow[b]{3}{*}{$\begin{array}{l}\text { Type } \\
\text { conditionality }\end{array}$} & \multirow[b]{3}{*}{ of } & \multicolumn{3}{|l|}{ A-Bench mark } & \multicolumn{3}{|c|}{ B - Cost without grace period } & \multicolumn{3}{|l|}{$\mathrm{C}-$ Full cost } \\
\hline & & \multicolumn{3}{|c|}{$\begin{array}{l}\begin{array}{l}\text { Dependent variable: Log commitment } \\
\text { creditors) }\end{array} \\
\text { (to official }\end{array}$} & \multicolumn{3}{|c|}{$\begin{array}{l}\text { Dependent variable: Log commitment (to official } \\
\text { creditors) }\end{array}$} & \multicolumn{3}{|c|}{$\begin{array}{l}\text { Dependent variable: Log commitment (to official } \\
\text { creditors) }\end{array}$} \\
\hline & & Whole sample & HIPC group & $\begin{array}{ll}\begin{array}{l}\text { Non } \\
\text { group }\end{array} & \text { HIPC } \\
\end{array}$ & Whole sample & HIPC group & Non HIPC group & Whole sample & HIPC group & Non HIPC group \\
\hline \multirow{2}{*}{\multicolumn{2}{|c|}{ VAC\&GEC }} & $.3897098^{* * *}$ & .4022056 & $.3359605^{* * * *}$ & $.3675062^{* *}$ & -.2038754 & $.3797934^{* * *}$ & $.3708045^{* *}$ & -.1969144 & \multirow{2}{*}{$\begin{array}{l}.3590482^{* * * *} \\
(.1407256)\end{array}$} \\
\hline & & $(.1264645)$ & $(.302601)$ & $(.1150544)$ & $(.1542694)$ & $(.3651852)$ & $(.1332237)$ & $(.1545824)$ & $(.3618328)$ & \\
\hline Prob $>$ chi2 2 & & 0.0000 & 0.0000 & 0.0000 & 0.0000 & 0.1614 & 0.0000 & 0.0000 & 0.1518 & 0.0000 \\
\hline \multirow{2}{*}{\multicolumn{2}{|c|}{ VAC\&RQC }} & $.383166^{* * *}$ & $.5107457^{*}$ & $.2257041^{*}$ & $.3544906^{* *}$ & -.0002993 & .2717479 & $.3574438^{* *}$ & .0043193 & .2449248 \\
\hline & & $(.1358777)$ & $(.2799201)$ & $(.1217843)$ & $(.1723408)$ & $(.417694)$ & $(.1732761)$ & $(.1724995)$ & $(.4081737)$ & $(.1703755)$ \\
\hline Prob $>$ chi 2 & & 0.0000 & 0.0000 & 0.0000 & 0.0000 & 0.1703 & 0.0005 & 0.0000 & 0.1660 & 0.0004 \\
\hline \multirow{2}{*}{\multicolumn{2}{|c|}{ VAC\&CCC }} & $.3023588 * *$ & .2099982 & $.2490699 *$ & $.3368192^{* *}$ & -.1748554 & $.4185721^{* * *}$ & $.3399094 * *$ & -.1670728 & $.394313^{* *}$ \\
\hline & & $(.1498152)$ & $(.316478)$ & $(.1325612)$ & $(.1587224)$ & $(.3956344)$ & $(.1548511)$ & $(.1588581)$ & $(.392841)$ & $(.1645275)$ \\
\hline Prob > chi2 & & 0.0000 & 0.0000 & 0.0000 & 0.0000 & 0.1610 & 0.0001 & 0.0000 & 0.1521 & 0.0000 \\
\hline \multirow{2}{*}{\multicolumn{2}{|c|}{ GEC\&RQC }} & .1809867 & .327588 & .2012379 & .2064555 & .0820825 & .0538794 & .2064514 & .0769185 & .0450729 \\
\hline & & $(.1243398)$ & $(.3455837)$ & $(.1314947)$ & $(.165135)$ & $(.5357644)$ & $(.1682197)$ & $(.1649052)$ & $(.5032272)$ & $(.167606)$ \\
\hline Prob > chi 2 & & 0.0000 & 0.0000 & 0.0000 & 0.0000 & 0.1781 & 0.0007 & 0.0000 & 0.1713 & 0.0003 \\
\hline \multirow{2}{*}{\multicolumn{2}{|c|}{ GEC\&CCC }} & -.02989 & $-.7820505^{* *}$ & .1759846 & .1954373 & -.4470595 & .0467568 & .196029 & -.4588197 & .0386765 \\
\hline & & $(.1636327)$ & $(.3791153)$ & $(.1378823)$ & $(.1979794)$ & $(.3270617)$ & $(.2096482)$ & $(.1974881)$ & $(.3195172)$ & $(.2108385)$ \\
\hline Prob $>$ chi2 & & 0.0000 & 0.0000 & 0.0000 & 0.0000 & 0.0211 & 0.0017 & 0.0000 & 0.0176 & 0.0008 \\
\hline \multirow{2}{*}{\multicolumn{2}{|c|}{ RQC\&CCC }} & .2388893 & .010158 & .2731976 & $.3163126^{*}$ & .126965 & .0682815 & $.3159879^{*}$ & .1110317 & .0680265 \\
\hline & & $(.1962172)$ & $(.3823118)$ & $(.2101343)$ & $(.1728613)$ & $(.3359464)$ & $(.1966705)$ & $(.1726432)$ & $(.3442631)$ & $(.1978458)$ \\
\hline Prob > chi2 & & 0.0000 & 0.0000 & 0.0000 & 0.0000 & 0.1728 & 0.0013 & 0.0000 & 0.1565 & 0.0006 \\
\hline $\begin{array}{l}\text { Number } \\
\text { Observations }\end{array}$ & of & 979 & 293 & 686 & 584 & 164 & 420 & 584 & 164 & 420 \\
\hline
\end{tabular}

Robust standard errors are reported in parenthesis below the coefficients. *** indicate the coefficient is different from zero at the 1 percent level, **at the 5 percent level, and * at the 10 percent level 
Table 4. Three sets of conditionality

\begin{tabular}{|c|c|c|c|c|c|c|c|c|c|}
\hline \multirow[b]{3}{*}{$\begin{array}{l}\text { Type of } \\
\text { conditionality }\end{array}$} & \multicolumn{3}{|l|}{ A - Bench mark } & \multicolumn{3}{|c|}{ B - Cost without grace period } & \multicolumn{3}{|l|}{$\mathrm{C}-$ Full cost } \\
\hline & \multicolumn{3}{|c|}{$\begin{array}{l}\text { Dependent variable: Log commitment (to official } \\
\text { creditors) }\end{array}$} & \multicolumn{3}{|c|}{$\begin{array}{l}\text { Dependent variable: Log commitment (to official } \\
\text { creditors) }\end{array}$} & \multicolumn{3}{|c|}{$\begin{array}{l}\text { Dependent variable: Log commitment (to official } \\
\text { creditors) }\end{array}$} \\
\hline & Whole sample & HIPC group & $\begin{array}{ll}\text { Non } & \text { HIPC } \\
\text { group } & \end{array}$ & Whole sample & HIPC group & $\begin{array}{ll}\text { Non } & \text { HIPC } \\
\text { group } & \end{array}$ & Whole sample & HIPC group & $\begin{array}{ll}\text { Non } & \text { HIPC } \\
\text { group } & \end{array}$ \\
\hline \multirow{2}{*}{$\begin{array}{l}\text { VAC, } \\
\text { RQC }\end{array}$} & $.4126422 * * *$ & $.4500113^{*}$ & $.3295131 * * *$ & $.4148917^{* * * *}$ & -.0365853 & $3902444 * * *$ & \multirow{2}{*}{$\begin{array}{l}.4169482^{* * * *} \\
(.1580999)\end{array}$} & -.0334246 & \multirow{2}{*}{$\begin{array}{l}.3669731^{* * *} \\
(.1468847)\end{array}$} \\
\hline & $(.1266886)$ & $(.2627437)$ & (.1167259) & $(.1580133)$ & $(.3740811)$ & $(.145202)$ & & $(.3655571)$ & \\
\hline Prob > chi2 & 0.0000 & 0.0000 & 0.0000 & 0.0000 & 0.1705 & 0.0000 & 0.0000 & 0.1649 & 0.0000 \\
\hline \multirow[t]{2}{*}{ VAC, GEC, CCC } & $.3344609 * *$ & .2099982 & $.2978779^{* * *}$ & $.408118^{* * *}$ & -.1748554 & $.3731559 * * *$ & \multirow{2}{*}{$\begin{array}{l}.4111569^{* * * *} \\
(.1580201)\end{array}$} & -.1670728 & $.3521986^{* *}$ \\
\hline & $(.1387458)$ & $(.316478)$ & (.118282) & $(.1578231)$ & (.3956344) & (.149744) & & $(.392841)$ & $(.1523621)$ \\
\hline Prob > chi 2 & 0.0000 & 0.0000 & 0.0000 & 0.0000 & 0.1610 & 0.0001 & 0.0000 & 0.1521 & 0.0001 \\
\hline \multirow{2}{*}{$\begin{array}{l}\mathrm{VAC}, \\
\mathrm{CCC}\end{array}$} & $.3430594 * *$ & .2759934 & $.2528411 * *$ & $.3927402 * *$ & .0003262 & $.2985379 *$ & $.3954807^{* *}$ & .0035862 & $.2716844 *$ \\
\hline & $(.147394)$ & $(.2950464)$ & $(.121192)$ & $(.1620949)$ & $(.3993049)$ & $(.1631016)$ & $(.1622109)$ & $(.3917564)$ & $(.1626452)$ \\
\hline Prob > chi 2 & 0.0000 & 0.0000 & 0.0000 & 0.0000 & 0.1678 & 0.0001 & 0.0000 & 0.1632 & 0.0001 \\
\hline \multirow[t]{2}{*}{ GEC, RQC, CCC } & .0872842 & -.1545311 & .1643997 & $.3094992^{* *}$ & -.0499332 & .1483459 & $.3095264 * *$ & -.0632513 & .1442659 \\
\hline & $(.1525661)$ & $(.4126651)$ & $(.1358878)$ & $(.1609431)$ & $(.4850332)$ & $(.1677264)$ & $(.1605427)$ & $(.480212)$ & $(.1685441)$ \\
\hline Prob > chi 2 & 0.0000 & 0.0000 & 0.0000 & 0.0000 & 0.1624 & 0.0008 & 0.0000 & 0.1649 & 0.0000 \\
\hline \multirow{2}{*}{$\begin{array}{l}\text { VAC, GEC, } \\
\text { RQC, CCC }\end{array}$} & $.3613118^{* * *}$ & .2759934 & $.3000244 * * *$ & $.4599144 * * *$ & .0003262 & $.3964118^{* *}$ & \multirow{2}{*}{$\begin{array}{l}.4621035^{* * *} \\
(.1647974)\end{array}$} & .0035862 & $.3727244 * *$ \\
\hline & $(.1411538)$ & $(.2950464)$ & $(.1163591)$ & $(.164782)$ & (.3993049) & $(.1653747)$ & & $(.3917564)$ & $(.1600293)$ \\
\hline Prob > chi 2 & 0.0000 & 0.0000 & 0.0000 & 0.0000 & 0.1678 & 0.0000 & 0.0000 & 0.1632 & 0.0000 \\
\hline $\begin{array}{l}\text { Number of } \\
\text { Observations }\end{array}$ & 979 & 293 & 686 & 584 & 164 & 420 & 584 & 164 & 420 \\
\hline
\end{tabular}

Robust standard errors are reported in parenthesis below the coefficients. *** indicate the coefficient is different from zero at the 1 percent level, **at the 5 percent level, and * at the 10 percent level.

\section{Robustness Test}

To examine the robustness of our earlier specifications to allay fears of our estimated results being a one off occurrence reported by the tables, we selected a set of candidates for some new specifications. Estimates from these null specifications are reported in Table 5. We started by specifying formally that without conditionality the external debt burden of the borrowing countries would be bad anyway. This assertion was refuted. Subsequent null specifications reported in Table 5 panel A suggest that our view on the association between the voice of accountability and external debt is founded. This is because the null stating otherwise was rejected for the whole sample, HIPC and Non-HIPC subsamples.

Null specifications for the rest of the single prescriptions were all rejected except the one for corruption control. Its null was not rejected for the whole sample and the Non-HIPC subsample. However, we ask for caution in interpreting this result because the result for the HIPC subsample was omitted for collinearity, which cast doubt on the other results that were not rejected earlier. 
Table 5. Robustness Test Results: Control vector is made up of one lag of the dependent variable, log interest rate, $\log$ deficit and $\log$ deficit.

\begin{tabular}{|c|c|c|c|}
\hline \multicolumn{4}{|c|}{ Panel A - one set of conditionality } \\
\hline \multirow[b]{2}{*}{ Type of conditionality } & \multicolumn{3}{|c|}{ Dependent variable: Log commitment (to official creditors) } \\
\hline & Whole sample & HIPC group & Non HIPC group \\
\hline VAC & $\begin{array}{l}.6718657 \\
(.5274436)\end{array}$ & - & $\begin{array}{l}.2363103 \\
(.4741996)\end{array}$ \\
\hline Prob > chi 2 & 0.0000 & 0.0000 & 0.0000 \\
\hline GEC & $\begin{array}{l}.3491601 \\
(.4924683)\end{array}$ & $\begin{array}{l}.0494109 \\
(.1914683)\end{array}$ & $\begin{array}{l}.6312057 \\
(.4571607)\end{array}$ \\
\hline Prob > chi 2 & 0.0144 & 0.0000 & 0.0000 \\
\hline RQC & $\begin{array}{l}.034557 \\
(.2190185)\end{array}$ & $\begin{array}{l}.0494109 \\
(.1914683)\end{array}$ & $\begin{array}{l}.0125946 \\
(.214286)\end{array}$ \\
\hline Prob > chi2 2 & 0.0530 & 0.0000 & 0.0015 \\
\hline $\mathrm{CCC}$ & $\begin{array}{l}-.7238119 * * * \\
(.2796384)\end{array}$ & - & $\begin{array}{l}-.3864139 * * * \\
(.1011868)\end{array}$ \\
\hline Prob > chi 2 & 0.0150 & 0.0000 & 0.0000 \\
\hline Number of Observations & 70 & 14 & 56 \\
\hline \multicolumn{4}{|c|}{ Panel B - two sets of conditionality } \\
\hline VAC, GEC & $\begin{array}{l}.4306678 \\
(.3942637)\end{array}$ & - & $\begin{array}{l}.1501768 \\
(.3033059)\end{array}$ \\
\hline Prob > chi 2 & 0.0075 & 0.0000 & 0.0000 \\
\hline VAC, RQC & $\begin{array}{l}.4306678 \\
(.3942637)\end{array}$ & - & $\begin{array}{l}.1501768 \\
(.3033059)\end{array}$ \\
\hline Prob > chi 2 & 0.0075 & 0.0000 & 0.0000 \\
\hline VAC, CCC & $\begin{array}{l}.235627 \\
(.247945)\end{array}$ & - & $\begin{array}{l}.0250834 \\
(.2103945)\end{array}$ \\
\hline Prob > chi 2 & 0.0364 & 0.0000 & 0.0006 \\
\hline GEC, RQC & $\begin{array}{l}.034557 \\
(.2190185)\end{array}$ & - & $\begin{array}{l}.0125946 \\
(.214286)\end{array}$ \\
\hline Prob $>$ chi 2 & 0.0530 & 0.0000 & 0.0015 \\
\hline GEC, CCC & $\begin{array}{l}-.0148152 \\
(.4836079)\end{array}$ & - & $\begin{array}{l}.3171766 \\
(.3919301)\end{array}$ \\
\hline Prob > chi 2 & 0.0235 & 0.0000 & 0.0000 \\
\hline $\mathrm{RQC}, \mathrm{CCC}$ & $\begin{array}{l}-.3692188 \\
(.3909166)\end{array}$ & - & $\begin{array}{l}-.1633829 \\
(.3415763)\end{array}$ \\
\hline Prob > chi 2 & 0.0481 & 0.0000 & 0.0010 \\
\hline Number of Observations & 70 & 14 & 56 \\
\hline \multicolumn{4}{|c|}{ Panel C-three sets of conditionality } \\
\hline VAC, GEC, RQC & $\begin{array}{l}.4306678 \\
(.3942637)\end{array}$ & - & $\begin{array}{l}.1501768 \\
(.3033059)\end{array}$ \\
\hline Prob $>$ chi 2 & 0.0075 & 0.0000 & 0.0000 \\
\hline VAC, GEC, CCC & $\begin{array}{l}.1392926 \\
(.2199615)\end{array}$ & - & $\begin{array}{l}.0213726 \\
(.1855755)\end{array}$ \\
\hline Prob > chi 2 & 0.0000 & 0.0000 & 0.0000 \\
\hline VAC, RQC, CCC & $\begin{array}{l}.1392926 \\
(.2199615)\end{array}$ & - & $\begin{array}{l}.0213726 \\
(.1855755)\end{array}$ \\
\hline Prob > chi 2 & 0.0000 & 0.0000 & 0.0000 \\
\hline GEC, RQC, CCC & $\begin{array}{l}-.3692188 \\
(.3909166)\end{array}$ & - & $\begin{array}{l}-.1633829 \\
(.3415763)\end{array}$ \\
\hline Prob > chi2 & 0.0481 & 0.0000 & 0.0010 \\
\hline VAC, GEC, RQC, CCC & $\begin{array}{l}.1392926 \\
(.2199615)\end{array}$ & - & $\begin{array}{l}.0213726 \\
(.1855755)\end{array}$ \\
\hline Prob $>$ chi 2 & 0.0000 & 0.0000 & 0.0000 \\
\hline Number of Observations & 70 & 14 & 56 \\
\hline
\end{tabular}

The (-) sign means dropped for collinearity.

Results reported by Table 5 panel B told that same story which was reported earlier. All the reported null estimates were rejected. The entire HIPC column had no reported results because of collinearity issues. There were no changes to the association claims for the three-conditionality sets too. Table 5 panels $\mathrm{C}$ reports the robustness test result of those claims. Just like its predecessor, all the reported null estimates were rejected for the whole sample column and the Non-HIPC subsample. The HIPC subsample did not have valid results because of collinearity.

\section{Concluding Remarks}

The IFIs represent a hope fountain that make significant portions of funds available for national developmental needs, and contribute in no small way to the policy directions of borrower countries and territories. Conditionality prescriptions and its implementation evolve structural changes and governance reforms, which affect the institutions in 
the borrower countries and territories. Understanding the impact that these policy inputs have on countries is important to informing a rethink in prescriptions and implementation of conditionality (when administering external assistance).

Our analysis of the effect of conditionality on external commitments of borrowers revealed a lot. Agreeing to and implementing the four proxies of conditionality increased the external commitments of borrower countries. Our estimates further indicated that corruption control efforts and improvement in government effectiveness reduced the external commitments of some borrower countries. However, a double and triple set of prescriptions implemented increased the external commitments of the borrowing countries. From these recounted results, we conclude that the existence of a debt trap is not only possible but is a situation, which is ongoing even at present between borrowers and the IFIs.

\section{References}

Abdildina, Z., \& Jaramillo-Vallejo, J. (2005). Streamlining conditionality in World Bank and International Monetary Fund-supported programs. Conditionality revisited, Washington DC: World Bank, 85-92.

Acemoglu, D., Johnson, S., \& Robinson, J. A. (2001). The colonial origins of comparative development: an empirical investigation. American Economic Review, 91, 1369-1401. http://dx.doi.org/10.1257/aer.91.5.1369

Arellano, M., \& Bond, S. (1991). Some tests of specification for panel data: Monte Carlo evidence and an application to employment equations. Review of Economic Studies, 58, 277-297. http://dx.doi.org/10.2307/2297968

Besley, T., \& Persson, T. (2010). State capacity, conflict, and development. Econometrica, 78(1), 1-34.

Bird, G. (1977). The International Monetary system and the Less Developed Countries. Development Policy Review. http://dx.doi.org/10.1111/j.1467-7679.1977.tb00259.x

Bruce, N., \& Waldman, M. (1991). Transfers in kind: why they can be efficient and non-paternalistic. American Economic Review, 81(5), 1345-1351.

Buchanan, J. M. (1968). What kind of redistribution do we want? Economica, 35, 185-190.

Dell, S. (1981). On being grandmotherly: the evolution of IMF conditionality. Essays in International Finance, 144, Princeton, New Jersey.

Dell, S. (1982). Stabilization: the political economy of overkill. World Development, 10(8), 597-612. http://dx.doi.org/10.1016/0305-750X(82)90088-2

Dhonte, P. (1997). Conditionality as an instrument of borrower credibility. Paper on Policy Analysis and Assessment of the IMF $97 / 2$.

Drazen, A. (2006). Conditionality and ownership in IMF lending: a political economy approach. Globalization and the Nation State. http://dx.doi.org/10.4324/9780203323441_chapter_3

Drazen, A., \& Isard, P. (2004). Can public discussion enhance program ownership? Money, Crises and Transition. http://dx.doi.org/10.7551/mitpress/9780262182669.003.0013

Dreher, A. (2004). The influence of IMF programs on the re-election of debtor governments. Economics \& Politics, 16(1), 53-76. http://dx.doi.org/10.1111/j.1468-0343.2004.00131.x

Dreher, A., \& Jensen, N. M. (2003). Independent actor or agent? An empirical analysis of the impact of US interests on IMF conditions. SSRN Electronic Journal. http://dx.doi.org/10.2139/ssrn.459280

Dreher, A., \& Vaubel, R. (2004). Do IMF and IBRD cause moral hazard and political business cycles? Evidence from panel data. Open Economies Review, 15(1), 5-22. http://dx.doi.org/10.1023/B:OPEN.0000009422.66952.4b

Dreher, A., Sturm, J. E., \& Vreeland, J. R. (2009). Global horse-trading: IMF loans for votes in the United Nations Security Council. European Economic Review, 53(7), 742-757. http://dx.doi.org/10.1016/j.euroecorev.2009.03.002

Eaton, J., \& Gersovitz, M. (1981). Debt with potential repudiation: theoretical and empirical analysis. The Review of Economic Studies, 48(2), 289-309. http://dx.doi.org/10.2307/2296886

Fafchamps, M. (1996). Sovereign debt, Structural Adjustment, and conditionality. Journal of Development Economics, 50, 313-335. http://dx.doi.org/10.1016/S0304-3878(96)00404-X

Feldstein, M. (1998). Refocusing the IMF. Foreign Affairs, March/April, 20-33. http://dx.doi.org/10.2307/20048786

Garfinkel, I. (1973). Is in-kind redistribution efficient? Quarterly Journal of Economics, 87, 320-330. http://dx.doi.org/10.2307/1882195

Goldstein, M. (2003). IMF structural programs. In Economic and Financial Crisis in Emerging Market Economies, 363-458. http://dx.doi.org/10.7208/chicago/9780226241104.003.0006 
Kapur, D., \& Webb, R. (2000). Governance-related conditionality of the International Financial Institutions. G-24 Discussion paper series

Khan, M. S., \& Sharma, S. (2001). IMF conditionality and country ownership of programs. IMF Institute, IMF. http://dx.doi.org/10.2139/ssrn.286968

Killick, T. (1995). IMF programs in Developing Countries-design and impact. London: Routledge.

Kletzer, K. (2005). Sovereign debt, volatility and insurance. SSRN Electronic Journal. http://dx.doi.org/10.2139/ssrn.892395

Kletzer, K. M. (1984). Asymmetries of information and LDC borrowing with sovereign risk. The Economic Journal, 94 , 287-307. http://dx.doi.org/10.2307/2232351

Koeberle, S. G. (2004). Conditionality: under what conditions? In S. Koeberle, H. Bedoya, P. Silarszky, \& G. Verheyen (Eds.), Conditionality Revisited (Pages 57-84). Washington: World Bank.

Krugman, P. (1988). Financing vs. forgiving a debt overhang. Journal of Development Economics, 29, 253-268. http://dx.doi.org/10.1016/0304-3878(88)90044-2

Little, I. M. D., \& Clifford, J. M. (1965). International aid. London: George Allen and Unwin Ltd.

Loxley, J. (1986). Debt and disorder-external financing for development. London: Westview Press.

Marchesi, S., \& Thomas, J. P. (1999). IMF conditionality as a screening device. Economic Journal, 109, C111-C125. http://dx.doi.org/10.1111/1468-0297.00420

Mauro, P. (1995). Corruption and growth. The Quarterly Journal of Economics, 110(3), 681-712. http://dx.doi.org/10.2307/2946696

Murphy, K. M., Shleifer, A., \& Vishny R. W. (2008). Why is rent-seeking so costly to growth. 40 Years of Research on Rent Seeking 2, Chapter 11. http://dx.doi.org/10.1007/978-3-540-79247-5_11

Murshed S. M., \& Raffer K. (1993). Trade, transfers, and development, problems and prospects for the twenty first century. (Eds), Edward Elgar Publishing Ltd, Aldershot (UK), 151-166.

North, D. C. (1981). Structure and change in economic history. New York: Norton \& Co.

Pande, R., \& Udry, C. (2007). Institutions and development: a view from below. Advances in Economics and Econometrics. http://dx.doi.org/10.1017/CCOL0521871530.014

Payer, C. (1975). The Debt Trap: The International Monetary Fund and the Third World. 376. NYU Press.

Radelet, S., \& Sachs, J. (1998). The East Asian financial crisis: diagnosis, remedies, and prospects. Brookings Papers on Economic Activity, 2, 357-371. http://dx.doi.org/10.2307/2534670

Raffer, K. (1993). International financial institutions and accountability: The need for drastic change. Trade, Transfers and Development, Problems and Prospects for the Twenty-First Century, Aldershot: Edward Elgar, pp. 151ff.

Rodrik, D. (1989). Promises, promises: credible policy reform via signaling. Economic Journal, 99, 756-772. http://dx.doi.org/10.2307/2233769

Rodrik, D. (1992). The limits of trade policy reform in developing countries. The Journal of Economic Perspectives, 6(1), 87-105. http://dx.doi.org/10.1257/jep.6.1.87

Sachs, J. (1989). Conditionality, debt relief, and the Developing Country debt crisis. In J. Sachs (Ed.), Developing Countries Debt and Economic Performance, Vol. 1. Chicago: University of Chicago Press.

Sachs, J., \& Cohen, D. (1982). LDC Borrowing with default risk. NBER Working Paper Series, Number w0925.

Spraos, J. (1986). Essays in international finance. 166. IMF Conditionality: Ineffectual, Inefficient, Mistargeted. Princeton: International Finance Section Princeton University.

Stiglitz, J. E. (2000). The contributions of the economics of information to twentieth century economics. Quarterly Journal of economics, 1441-1478. http://dx.doi.org/10.1162/003355300555015

Svensson, J. (2000). When is foreign aid policy credible? Aid dependence and conditionality. Journal of Development Economics, 61, 61-84. http://dx.doi.org/10.1016/S0304-3878(99)00061-9

Vaubel, R. (1983). The moral hazard of IMF lending. The World Economy, 6(3), 291-304. http://dx.doi.org/10.1111/j.1467-9701.1983.tb00015.x

Vaubel, R. (1991). The political economy of the International Monetary Fund: a public choice analysis. In R. Vaubel \& T. D. Willett (Eds.), The political economy of international organizations: a public choice approach, 205-245. 
Boulder: Westview Press.

Worrall, T. (1990). Debt with potential repudiation: short-run and long run contracts. European Economic Review, 34(5), 1099-1109. http://dx.doi.org/10.1016/0014-2921(90)90025-T

\section{Copyrights}

Copyright for this article is retained by the author(s), with first publication rights granted to the journal.

This is an open-access article distributed under the terms and conditions of the Creative Commons Attribution license (http://creativecommons.org/licenses/by/3.0/). 